Tropical Journal of Pharmaceutical Research October 2011; 10 (5): 643-653

(C) Pharmacotherapy Group,

Faculty of Pharmacy, University of Benin

Benin City, 300001 Nigeria.

All rights reserved.

Available online at http://www.tjpr.org

Research Article

http://dx.doi.org/10.4314/tjpr.v10i5.14

\title{
Development and Validation of a Dissolution Test Method for Artemether and Lumefantrine in Tablets
}

\author{
P Umapathi ${ }^{1^{*}}$, J Ayyappan ${ }^{2}$ and S Darlin Quine ${ }^{3}$ \\ ${ }^{1}$ Department of Analytical Research and Development, Micro Labs Ltd, 67/68-A, Third Phase, Peenya Industrial \\ Area, Bangalore 560 058, ${ }^{2}$ SASTRA University, Thanjavur, Tamil Nadu, ${ }^{3} P G$ and Research Department of Chemistry, \\ Government Arts College, Chidambaram, India
}

\begin{abstract}
Purpose: To develop and validate a dissolution test method for dissolution release of artemether and lumefantrine from tablets.

Methods: A single dissolution method for evaluating the in vitro release of artemether and lumefantrine from tablets was developed and validated. The method comprised of a dissolution medium of $1000 \mathrm{ml}$ of $2 \% \mathrm{w} / \mathrm{v}$ of Myrj 52 in $0.005 \mathrm{M} \mathrm{HCl}$ per vessel with the paddle rotating at $100 \mathrm{rpm}$ for $120 \mathrm{~min}$. The dissolution samples were analysed using a Waters HPLC system with Waters symmetry column (C-18 column of $250 \mathrm{~mm} \times 4.6 \mathrm{~mm}$ i.d., $5 \mu$ particle size). The mobile phase was a mixture of 20 volumes of 0.5 $\% \mathrm{v} / \mathrm{v}$ of triethylamine in water (adjusted to a $\mathrm{pH}$ of 3.0 with orthophosphoric acid) and 80 volumes of acetonitrile. The detection wavelength was set at $216 \mathrm{~nm}$ and $100 \mu \mathrm{l}$ of each sample was injected. The HPLC method used for the determination of drug release was validated for the parameters of accuracy, precision, linearity, specificity, filter validation, solution stability and robustness.

Results: The dissolution test provided sink conditions for artemether and lumefantrine and was able to discriminate between tablet formulations of different hardness and different composition. Application of Mann-Whitney $U$ test for significant difference between samples at various time points during the dissolution test yielded $z$ values $>1.96(1.96=$ critical $z$ value at $p=0.05)$ for the various formulations tested, indicating the discriminatory power of the dissolution test.

Conclusion: This validated dissolution test may be used as a single dissolution test for artemether and luminfantrine in tablet formulations.
\end{abstract}

Keywords: Artemether, Lumefantrine, Tablet formulations, Single dissolution test, HPLC 


\section{INTRODUCTION}

Artemether is a drug used for the treatment of malaria [1,2]. Artemether and lumefantrine combination is a fixed dose artemisinin-based combination therapy (ACT) combining artemether, an artemisinin derivative, and lumefantrine, a synthetic antimalarial drug for the treatment of malaria [3,4]. Artemether is a fast acting drug with a short half-life. Lumefantrine acts slowly and has a longer half-life. On oral administration, the plasma concentration of artemether reaches peak level after $2 \mathrm{~h}$ while the peak plasma concentration of lumefantrine is attained after 6 - 8 h [ 5 ].

The International Pharmacopoeia monograph of artemether and lumefantrine tablet does not include a dissolution test [6]. No common single dissolution test method for simultaneous dissolution testing of artemether and lumefantrine tablets has been reported in the literature although separate dissolution methods for artemether and lumefantrine have been developed [7]. Artemether is poorly soluble in water while lumefantrine is practically insoluble in water. In general, developing an appropriate single dissolution method of discriminatory nature to evaluate the dissolution release of poorly soluble drugs from dosage forms has been a lingering challenge. [8-11]

In the present study, a single dissolution test method for the dissolution release of artemether and lumefantrine which will be very useful for quality control of combination tablets has been designed and validated in terms of the discriminatory power of the dissolution test. The HPLC method used for analysis has been validated at our laboratory.

\section{EXPERIMENTAL}

\section{Reagents and materials}

The working standards of artemether (99.4\% purity) and lumefantrine (98.3\% purity) were obtained from Micro Labs Ltd, India. Three reference products ( $A, B$ and $C$ ), each containing $20 \mathrm{mg}$ of artemether and $120 \mathrm{mg}$ of lumefantrine were obtained from Indian market. The test tablet product used was manufactured in-house. Water purified with Millipore Water Purification System (Elix $10 \mathrm{C}$ model) was used for the preparation of buffers. Sodium acetate trihydrate, glacial acetic acid AR, potassium dihydrogen phosphate and sodium hydroxide pellets were sourced from Merck, India. PTFE membrane filters $(0.45 \mu$, syringe filter $25 \mathrm{~mm}$ GD/X- Whatman) were used for filtration of standard and sample solutions. Cellulose acetate filter $(0.45 \mu$, Sartorium stedim) was used for the filtration of the mobile phase.

\section{Instrumentation}

The dissolution test was carried out using an Electrolab Dissolution Test System (Model TDT-08L). A Waters HPLC system equipped with a 2695 solvent delivery system, Waters auto injector, thermostatted column compartment and Waters 2998 photo diode array detector was used. Waters Symmetry column (C-18 column of $250 \mathrm{~mm} \times 4.6 \mathrm{~mm}$ i.d., $5 \mu$ particle size) was used for the analysis.

\section{Determination of solubility of artemether and lumefantrine}

The solubility of artemether and lumefantrine was determined in the various dissolution media as follows. Artemether $(500 \mathrm{mg})$ and lumefantrine $(500 \mathrm{mg})$ were transferred into separate $100 \mathrm{ml}$ conical flasks. Dissolution medium $(50 \mathrm{ml})$ was added to each flask and the flasks were closed with Teflon-lined screw caps. These flasks were sonicated for $2 \mathrm{~h}$ at $37^{\circ} \mathrm{C}$ with intermittent shaking. The solutions were each filtered, through a $0.45 \mu$ Whatman membrane filter. Each filtrate was analysed separately by HPLC to determine the solubility of the drug in the particular dissolution medium. 
Evaluation of stability of the drug
solutions

The stability of artemether and lumefantrine in different dissolution media was evaluated at room temperature by calculating the change in peak area of samples at different time points which was then compared with that of the same sample immediately after injection.

\section{Stirring rate and dissolution medium}

Dissolution experiments were performed using standard USP dissolution apparatus 1 (basket) and apparatus 2 (paddle). Stirring rates of $100 \mathrm{rpm}$ for basket, and 50, 75 and $100 \mathrm{rpm}$ for paddle were evaluated. All the dissolution media used were de-aerated by sonication followed by filtration using membrane filter under vacuum.

\section{Sample preparation and determination}

The dissolution test was carried out using 1, 1.5 and $2 \%$ w/v of Myrj 52 (polyoxyl 40 stearate) in $0.005 \mathrm{M}$ hydrochloric acid. Sample aliquots of $5.0 \mathrm{ml}$ were withdrawn at different time points up to $120 \mathrm{~min}$. After each withdrawal, a volume of dissolution medium equal to the volume of sample withdrawn was added to each vessel to maintain the volume in each vessel. The samples were filtered and analysed by HPLC and the percent drug release at each dissolution time point calculated.

\section{Selection of sample filtration procedure}

The filtration procedure for standard and sample solutions was evaluated using $2.5 \mu$ pore filter paper (Whatman), $0.45 \mu$ PTFE syringe filter (Whatman) and $0.45 \mu$ nylon syringe filter (Advanced Microdevices, India)

\section{Discriminatory power}

The discriminatory power of the dissolution test was evaluated by (a) comparison of the dissolution results of reference products $A, B$, $C$ and in-house test product (b) comparison of the dissolution results of in-house test product of various hardness (c) comparison of test results of the test products stored at $40{ }^{\circ} \mathrm{C}$ and $75 \% \mathrm{RH}$ with those of the test products stored at room temperature and humidity $\left(23{ }^{\circ} \mathrm{C} / 60 \% \mathrm{RH}\right)$

\section{Chromatographic conditions}

The dissolution samples were analysed using Waters HPLC system, Symmetry column (C18 column of $250 \mathrm{~mm} \times 4.6 \mathrm{~mm}$ i.d., $5 \mu$ particle size) with a mobile phase of a mixture of buffer and acetonitrile $(20: 80, \mathrm{v} / \mathrm{v})$ at a flow rate of $1.0 \mathrm{ml} / \mathrm{min}$. The buffer for mobile phase was prepared by diluting $5 \mathrm{ml}$ of triethylamine to $1000 \mathrm{ml}$ with water and adjusting the $\mathrm{pH}$ to $3.0 \pm 0.05$ using orthophosphoric acid. The detection wavelength was set at $216 \mathrm{~nm}$ and $100 \mu \mathrm{l}$ of each sample was injected.

\section{Preparation of lumefantrine standard stock solution}

About $240 \mathrm{mg}$ of lumefantrine working standard was accurately weighed and transferred into a $100 \mathrm{ml}$ volumetric flask. About $25 \mathrm{ml}$ of mobile phase and one drop of orthophosphoric acid were added, the solution sonicated to dissolve the drug and the volume made up to $100 \mathrm{ml}$ with mobile phase.

\section{Artemether standard stock solution}

About $20 \mathrm{mg}$ of artemether working standard was accurately weighed and transferred into a $100 \mathrm{ml}$ volumetric flask. About $5 \mathrm{ml}$ of acetonitrile was added and the solution was sonicated to dissolve the substance; the volume was then made up to $100 \mathrm{ml}$ with dissolution medium.

\section{Standard solution}

Lumefantrine standard stock solution $(5 \mathrm{ml}$ ) and $10 \mathrm{ml}$ of artemether standard stock solution were transferred into a $100 \mathrm{ml}$ volumetric flask and made up to volume with dissolution medium to obtain a concentration of $120 \mu \mathrm{g}$ of lumefantrine and $20 \mu \mathrm{g}$ of artemether per $\mathrm{ml}$. This solution was filtered through $0.45 \mu$ PTFE membrane filter 
(Whatman) and the filtrate used as standard solution.

\section{Sample solution}

During the dissolution test, $5 \mathrm{ml}$ aliquots were withdrawn from the dissolution medium at various time points up to $120 \mathrm{~min}$ and replaced with an equal volume of fresh dissolution medium after each withdrawal to maintain a constant volume of the dissolution medium in the vessel. The samples were filtered through $0.45 \mu$ PTFE membrane filter (Whatman) and the filtrate used as sample solution.

\section{System suitability parameters}

System suitability parameters of not less than 5.0 resolution between artemether and lumefantrine peaks, not more than 2.0 tailing factor for each peak, not less than 2000 theoretical plates for each peak and a \%RSD of not more than 2.0 for five replicates of standard injection were specified as the system suitability requirements for the analytical method.

\section{Method validation}

The HPLC method was validated for specificity, linearity, precision, accuracy, filter validation, solution stability and robustness according to USP and ICH guidelines [12,13].

\section{Statistical analysis}

The dissolution values of the various formulations at different time points were compared using similarity factor (f2) and difference factor (f1) which were calculated using Eqs 1 and 2 ..

$$
\begin{aligned}
& f_{1}=\left\{\left[\sum_{t=1}{ }^{n}\left(R_{t}-T_{t}\right)\right] /\left[\sum_{t=1}{ }^{n} R_{t}\right]\right\} \times 100 \ldots \ldots \ldots \ldots . . \\
& f_{2}=50 \times \log \left\{\left[1+(1 / n) \sum_{t=1}{ }^{n}\left(R_{t}-T_{t}\right)^{2}\right]^{-0.5} \times 100\right\} \ldots . .
\end{aligned}
$$

where $R_{t}$ and $T_{t}$ are the cumulative percentage dissolved at each of the selected ' $n$ ' time points of the reference and test product respectively

The calculation was performed with Microsoft Office Excel 2003. The difference between the dissolution values of various formulations was evaluated using Mann-Whitney $U$ test and the calculated $z$ values were compared with the critical $z$ value of $1.96(p=0.05)$. This calculation was carried out using a web calculator [14]. The \%RSD value and the linear regression analysis by the method of least squares were calculated using Excel program.

\section{RESULTS}

The solubility and stability data for artemether and lumefantrine in various commonly used dissolution media are presented in Tables 1 and 2 on the basis of which the most suitable dissolution medium was selected.

The dissolution values of reference product $A$ in $0.005 \mathrm{M} \mathrm{HCl}$ containing $1.0,1.5$ and $2.0 \%$ $\mathrm{w} / \mathrm{v}$ of Myrj 52 are presented in Table 3 while those of the reference products $A, B, C$ and the test product in the selected dissolution medium of $2 \% \mathrm{w} / \mathrm{v}$ Myrj 52 in $0.005 \mathrm{~N}$ hydrochloric acid at various time points are presented in Table 4. The dissolution results of a formulation at a particular time point were different from those of other formulations at the same time point as per the Mann-Whitney $U$ test. The difference factor (f1) values for the various formulations indicate significant difference in the release pattern of the formulations when compared with reference product $A$.

\section{Validation of the HPLC method}

The validation results for the HPLC method used for the determination of drug release are as follows.

\section{Accuracy}

The accuracy of the method in the range of 25 to $150 \%$ of test concentration of artemether $(20 \mu \mathrm{g} / \mathrm{ml}$ of artemether $)$ and lumefantrine $(120 \mu \mathrm{g} / \mathrm{ml}$ of lumefantrine) was satisfactory. Recovery (\% was between 98.52 to $99.49 \%$ for artemether and 98.48 to $99.73 \%$ for lumefantrine.

Trop J Pharm Res, October 2011;10(5):646 
Table 1: Solubility of artemether and lumefantrine in various dissolution media $(n=3)$

\begin{tabular}{|c|c|c|}
\hline \multirow[t]{2}{*}{ Medium } & \multicolumn{2}{|c|}{$\begin{array}{c}\text { Concentration } \\
(\mu \mathrm{g} / \mathrm{ml}, \text { mean } \pm \mathrm{SD})\end{array}$} \\
\hline & Artemether & Lumefantrine \\
\hline Water & $133 \pm 4$ & Insoluble \\
\hline $0.1 \mathrm{~N}$ Hydrochloric acid & $127 \pm 5$ & Insoluble \\
\hline pH 4.5 Acetate buffer & $130 \pm 4$ & Insoluble \\
\hline pH 6.8 Phosphate buffer & $119 \pm 6$ & Insoluble \\
\hline $1 \% \mathrm{w} / \mathrm{v}$ SLS in Water & $4107 \pm 12$ & $16 \pm 2$ \\
\hline $1 \% \mathrm{w} / \mathrm{v}$ SLS in $0.1 \mathrm{~N}$ Hydrochloric acid & $2633 \pm 21$ & $216 \pm 3$ \\
\hline $1 \% \mathrm{w} / \mathrm{v}$ SLS in $\mathrm{pH} 4.5$ Acetate buffer & $3896 \pm 11$ & $238 \pm 4$ \\
\hline $1 \%$ w/v SLS in pH 6.8 Phosphate buffer & $3511 \pm 9$ & $79 \pm 10$ \\
\hline $1 \% \mathrm{w} / \mathrm{v} \mathrm{BKC}$ in Water & $1230 \pm 8$ & $11 \pm 2$ \\
\hline $1 \% \mathrm{w} / \mathrm{v} \mathrm{BKC}$ in $0.1 \mathrm{~N}$ Hydrochloric acid & $1055 \pm 17$ & $119 \pm 3$ \\
\hline $1 \% \mathrm{w} / \mathrm{v} \mathrm{BKC}$ in $\mathrm{pH} 4.5$ Acetate buffer & $1246 \pm 12$ & $6 \pm 1$ \\
\hline $1 \% \mathrm{w} / \mathrm{v} \mathrm{BKC}$ in $\mathrm{pH} 6.8$ Phosphate buffer & $1275 \pm 11$ & $3 \pm 1$ \\
\hline $1 \%$ w/v CTAB in Water & $2544 \pm 6$ & $11 \pm 2$ \\
\hline $1 \% \mathrm{w} / \mathrm{v}$ CTAB in $0.1 \mathrm{~N}$ Hydrochloric acid & $2469 \pm 16$ & $175 \pm 3$ \\
\hline $1 \% \mathrm{w} / \mathrm{v}$ CTAB in $\mathrm{pH} 4.5$ Acetate buffer & $2555 \pm 9$ & $23 \pm 2$ \\
\hline $1 \%$ w/v CTAB in $\mathrm{pH} 6.8$ Phosphate buffer & $2589 \pm 5$ & $3 \pm 1$ \\
\hline $1 \%$ w/v Tween 80 in Water & $643 \pm 6$ & $11 \pm 1$ \\
\hline $1 \%$ w/v Tween 80 in $0.1 \mathrm{~N}$ Hydrochloric acid & $639 \pm 23$ & $272 \pm 5$ \\
\hline 1\% w/v Tween 80 in pH 4.5 Acetate buffer & $641 \pm 8$ & $25 \pm 2$ \\
\hline $1 \%$ w/v Tween 80 in $\mathrm{pH} 6.8$ Phosphate buffer & $661 \pm 6$ & $7 \pm 1$ \\
\hline 1\% w/v Myrj 52 in Water & $536 \pm 7$ & $34 \pm 2$ \\
\hline $1 \%$ w/v Myrj 52 in $0.1 \mathrm{~N}$ Hydrochloric acid & $503 \pm 19$ & $813 \pm 4$ \\
\hline 1\% w/v Myrj 52 in pH 4.5 Acetate buffer & $524 \pm 8$ & $19 \pm 2$ \\
\hline $1 \%$ w/v Myrj 52 in pH 6.8 Phosphate buffer & $528 \pm 7$ & $7 \pm 1$ \\
\hline $1 \%$ w/v Myrj 52 in $0.005 \mathrm{~N}$ Hydrochloric acid & $603 \pm 4$ & $463 \pm 5$ \\
\hline $1.5 \%$ w/v Myrj 52 in $0.005 \mathrm{~N}$ Hydrochloric acid & $897 \pm 4$ & $616 \pm 4$ \\
\hline $2 \%$ w/v Myrj 52 in $0.005 \mathrm{~N}$ Hydrochloric acid & $1077 \pm 5$ & $732 \pm 6$ \\
\hline
\end{tabular}

\section{Precision}

The intra-day and inter-day precision, compared in terms of \%RSD, were close to each other indicating satisfactory level of precision of the method. \%RSD for intra-day precision was 1.33 and 1.51 for artemether and 1.23 and 1.33 for lumefantrine on first and second day of analysis, respectively while\%RSD for inter-day precision was 1.37 for artemether and 1.27 for lumefantrine

\section{Linearity}

The analytical method was linear for artemether and lumefantrine in the concentration range of $5-150 \%$ of test concentration of the drugs. The test concentration of artemether was $20 \mu \mathrm{g} / \mathrm{ml}$ and that of lumefantrine $120 \mu \mathrm{g} / \mathrm{ml}$. The regression analysis of the linearity data yielded correlation coefficient values above 0.9990 for each drug (see Table 5).

\section{Specificity}

The specificity of the method was ascertained from the absence of peaks in the chromatogram of the dissolution medium at the retention times of artemether $(\mathrm{Rt}=8.03$ $\mathrm{min}$ ) and lumefantrine ( $\mathrm{Rt}=5.34 \mathrm{~min}$ ) as well as from the purity angle values. For artemether, the purity angle was 0.849 and 0.824 while the purity threshold was 1.269 and 1.312 in standard and sample solutions, respectively. Similarly, for lumefantrine the purity angle was 1.656 and 1.632 while the purity threshold was 9.897 and 9.832 in 
Umapathi et al

Table 2: Stability of artemether and lumefantrine in various dissolution media $(n=3)$

\begin{tabular}{|c|c|c|c|c|c|c|c|c|}
\hline \multirow[b]{3}{*}{ Medium } & \multicolumn{8}{|c|}{ Percent peak area reduction* } \\
\hline & \multicolumn{4}{|c|}{ Artemether } & \multicolumn{4}{|c|}{ Lumefantrine } \\
\hline & $\begin{array}{l}\text { At } 0 \\
\text { hour }\end{array}$ & $\begin{array}{c}\text { After } \\
2 \\
\text { hours }\end{array}$ & $\begin{array}{c}\text { After } \\
6 \\
\text { hours }\end{array}$ & $\begin{array}{l}\text { After } 10 \\
\text { hours }\end{array}$ & $\begin{array}{l}\text { At } 0 \\
\text { hour }\end{array}$ & $\begin{array}{l}\text { After } 2 \\
\text { hours }\end{array}$ & $\begin{array}{l}\text { After } 6 \\
\text { hours }\end{array}$ & $\begin{array}{l}\text { After } 10 \\
\text { hours }\end{array}$ \\
\hline Water & 0 & 0.61 & 1.12 & 1.96 & \multirow{4}{*}{\multicolumn{4}{|c|}{$\begin{array}{l}\text { Insoluble } \\
\text { Insoluble } \\
\text { Insoluble } \\
\text { Insoluble }\end{array}$}} \\
\hline $0.1 \mathrm{~N} \mathrm{HCl}$ & 0 & 26.19 & 57.41 & 74.33 & & & & \\
\hline pH 4.5 Acetate buffer & 0 & -0.26 & 2.03 & 0.79 & & & & \\
\hline $\begin{array}{l}\text { pH } 6.8 \text { Phosphate } \\
\text { buffer }\end{array}$ & 0 & -0.36 & 1.15 & 1.31 & & & & \\
\hline $1 \% \mathrm{w} / \mathrm{v}$ SLS in Water & 0 & -2.33 & 1.38 & -0.86 & 0 & 0 & 0.00 & 0.04 \\
\hline $\begin{array}{l}1 \% \text { w/v SLS in } 0.1 \mathrm{~N} \\
\text { Hydrochloric acid }\end{array}$ & 0 & 54.27 & 88.39 & 100 & 0 & 0.01 & 0.01 & -0.04 \\
\hline $\begin{array}{l}1 \% \text { w/v SLS in pH } 4.5 \\
\text { Acetate buffer }\end{array}$ & 0 & -0.14 & 0.98 & 0.35 & 0 & 0.18 & 0.04 & 0.80 \\
\hline $\begin{array}{l}1 \% \text { w/v SLS in pH } 6.8 \\
\text { Phosphate buffer }\end{array}$ & 0 & 0.43 & -0.29 & 0.57 & 0 & 3.30 & 7.02 & 9.10 \\
\hline $1 \% \mathrm{w} / \mathrm{v}$ BKC in Water & 0 & 0.69 & 0.37 & 0.39 & 0 & 0.13 & 0.48 & 0.96 \\
\hline $\begin{array}{l}1 \% \text { w/v BKC in } 0.1 \mathrm{~N} \\
\text { Hydrochloric acid }\end{array}$ & 0 & 1.73 & 12.16 & 17.74 & 0 & 0.06 & 0.05 & 0.05 \\
\hline $\begin{array}{l}1 \% \text { w/v BKC in } \mathrm{pH} 4.5 \\
\text { Acetate buffer }\end{array}$ & 0 & 1.27 & 0.85 & 0.28 & 0 & -0.05 & -0.01 & 0.01 \\
\hline $\begin{array}{l}1 \% \text { w/v BKC in } \mathrm{pH} 6.8 \\
\text { Phosphate buffer }\end{array}$ & 0 & 0.00 & -0.14 & 0.28 & 0 & 4.67 & 27.42 & 51.53 \\
\hline $\begin{array}{l}1 \% \text { w/v CTAB in } \\
\text { Water }\end{array}$ & 0 & -0.86 & 0.13 & -0.57 & 0 & -0.08 & 0.11 & 0.26 \\
\hline $\begin{array}{l}1 \% \text { w/v CTAB in } 0.1 \mathrm{~N} \\
\mathrm{HCl}\end{array}$ & 0 & 1.49 & 7.08 & 9.86 & 0 & 0.03 & 0.34 & 0.45 \\
\hline $\begin{array}{l}1 \% \text { w/v CTAB in } \mathrm{pH} \\
4.5 \text { Acetate buffer }\end{array}$ & 0 & 0.14 & -0.14 & 0.95 & 0 & 0.03 & -0.14 & 0.30 \\
\hline $\begin{array}{l}1 \% \mathrm{w} / \mathrm{v} \text { CTAB in } \mathrm{pH} \\
6.8 \text { Phosphate buffer }\end{array}$ & 0 & 0.14 & 0.42 & 0.42 & 0 & 0.16 & 1.70 & 8.72 \\
\hline $\begin{array}{l}1 \% \mathrm{w} / \mathrm{v} \text { Tween } 80 \text { in } \\
\text { Water }\end{array}$ & 0 & -0.15 & 0.45 & 0.75 & 0 & -0.07 & 0.41 & 0.50 \\
\hline $\begin{array}{l}1 \% \mathrm{w} / \mathrm{v} \text { Tween } 80 \text { in } \\
0.1 \mathrm{~N} \mathrm{HCl}\end{array}$ & 0 & 9.61 & 19.47 & 29.94 & 0 & 1.50 & 2.76 & 6.24 \\
\hline $\begin{array}{l}1 \% \text { w/v Tween } 80 \text { in } \\
\mathrm{pH} 4.5 \text { Acetate buffer }\end{array}$ & 0 & 0.42 & -0.28 & 0.85 & 0 & 0.01 & 0.02 & 0.55 \\
\hline $\begin{array}{l}1 \% \text { w/v Tween } 80 \text { in } \\
\mathrm{pH} 6.8 \text { Phosphate }\end{array}$ & 0 & 0.28 & 0.42 & 0.14 & & & & \\
\hline buffer & & & & & 0 & 0.02 & 0.19 & 0.61 \\
\hline $\begin{array}{l}1 \% \text { w/v Myrj } 52 \text { in } \\
\text { Water }\end{array}$ & 0 & -0.56 & 0.56 & 0.14 & 0 & 0.02 & 0.02 & 0.32 \\
\hline 1\% w/v Myrj 52 in & 0 & & & & & & & \\
\hline $\begin{array}{l}0.1 \mathrm{~N} \text { Hydrochloric } \\
\text { acid }\end{array}$ & & 9.60 & 20.47 & 31.81 & 0 & 0.23 & 0.57 & 0.68 \\
\hline $\begin{array}{l}1 \% \text { w/v Myrj } 52 \text { in } \mathrm{pH} \\
4.5 \text { Acetate buffer }\end{array}$ & 0 & 0.14 & 0.70 & 0.14 & 0 & 0.28 & 0.31 & 0.58 \\
\hline $\begin{array}{l}1 \% \text { w/v Myrj } 52 \text { in pH } \\
6.8 \text { Phosphate buffer }\end{array}$ & 0 & 0.14 & -0.28 & 0.28 & 0 & 0.16 & 2.60 & 9.16 \\
\hline $\begin{array}{l}1 \% \text { w/v Myrj } 52 \text { in } \\
0.005 \mathrm{~N} \mathrm{HCl}\end{array}$ & 0 & 0.10 & 0.21 & 0.43 & 0 & 0.02 & 0.01 & 0.02 \\
\hline $\begin{array}{l}1.5 \% \text { w/v Myrj } 52 \text { in } \\
0.005 \mathrm{~N} \mathrm{HCl}\end{array}$ & 0 & 0.10 & 0.20 & 0.41 & 0 & 0.01 & 0.02 & 0.03 \\
\hline $\begin{array}{l}2 \% \text { w/v Myrj } 52 \text { in } \\
0.005 \mathrm{~N} \mathrm{HCl}\end{array}$ & 0 & 0.12 & 0.22 & 0.44 & 0 & 0.02 & 0.03 & 0.05 \\
\hline
\end{tabular}

$S L S=$ Sodium lauryl sulphate $\quad B K C=$ Benzalkonium chloride $\quad C T A B=$ Cetyl trimethylammonium bromide 
Table 3: Dissolution profile of reference product $\mathrm{A}$ in $0.005 \mathrm{M} \mathrm{HCl}$ containing $1,1.5$ and 2.\%w/v of Myrj 52 (n $=24)$

\begin{tabular}{|c|c|c|c|c|}
\hline \multirow{3}{*}{$\begin{array}{l}\text { Time } \\
(\min )\end{array}$} & Basket 100 RPM & Paddle 50 RPM & Paddle 75 RPM & Paddle 100 RPM \\
\hline & \multicolumn{4}{|c|}{$1 \%$ w/v Myrj 52 in $0.005 M$ hydrochloric acid } \\
\hline & \multicolumn{4}{|c|}{$\%$ Artemether release (mean $\pm S D$ ) } \\
\hline 30 & $35.2 \pm 2.6$ & $39.6 \pm 2.2$ & $44.2 \pm 3.2$ & $53.4 \pm 2.8$ \\
\hline 60 & $47.5 \pm 2.1$ & $55.3 \pm 2.9$ & $64.6 \pm 2.6$ & $78.4 \pm 2.1$ \\
\hline 90 & $62.5 \pm 1.8$ & $73.2 \pm 2.7$ & $82.3 \pm 1.9$ & $95.4 \pm 1.4$ \\
\hline \multirow[t]{2}{*}{120} & $74.7 \pm 1.3$ & $80.1 \pm 2.3$ & $89.4 \pm 1.4$ & $98.5 \pm 1.1$ \\
\hline & \multicolumn{4}{|c|}{$\%$ Lumefantrine release (mean $\pm S D)$} \\
\hline 30 & $19.5 \pm 1.3$ & $21.4 \pm 1.7$ & $26.3 \pm 2.1$ & $35.4 \pm 1.5$ \\
\hline 60 & $35.3 \pm 1.7$ & $37.5 \pm 2.6$ & $44.4 \pm 2.1$ & $53.4 \pm 2.2$ \\
\hline 90 & $52.4 \pm 2.5$ & $56.6 \pm 2.9$ & $60.6 \pm 2.2$ & $65.4 \pm 3.1$ \\
\hline \multirow[t]{3}{*}{120} & $62.9 \pm 2.4$ & $64.5 \pm 2.3$ & $68.3 \pm 3.1$ & $73.7 \pm 2.9$ \\
\hline & \multicolumn{4}{|c|}{$1.5 \%$ w/v Myrj 52 in $0.005 M$ hydrochloric acid } \\
\hline & \multicolumn{4}{|c|}{$\%$ Artemether release (mean $\pm S D)$} \\
\hline 30 & $37.2 \pm 2.8$ & $45.4 \pm 3.1$ & $54.4 \pm 2.4$ & $58.4 \pm 2.9$ \\
\hline 60 & $57.3 \pm 3.1$ & $65.1 \pm 2.8$ & $77.4 \pm 2.5$ & $84.6 \pm 2.1$ \\
\hline 90 & $74.6 \pm 2.6$ & $83.7 \pm 1.9$ & $94.4 \pm 1.9$ & $98.6 \pm 1.7$ \\
\hline \multirow{2}{*}{120} & $79.6 \pm 2.1$ & $88.6 \pm 1.4$ & $97.8 \pm 1.4$ & $100.8 \pm 1.1$ \\
\hline & \multicolumn{4}{|c|}{$\%$ Lumefantrine release (mean $\pm S D$ ) } \\
\hline 30 & $22.3 \pm 1.3$ & $23.4 \pm 1.1$ & $36.8 \pm 1.2$ & $41.4 \pm 1.8$ \\
\hline 60 & $38.7 \pm 3.3$ & $44.4 \pm 2.4$ & $55.3 \pm 2.8$ & $60.4 \pm 2.9$ \\
\hline 90 & $55.4 \pm 2.7$ & $61.1 \pm 3.1$ & $66.4 \pm 3.1$ & $76.3 \pm 2.7$ \\
\hline \multirow[t]{3}{*}{120} & $64.1 \pm 3.3$ & $67.2 \pm 2.9$ & $71.7 \pm 2.8$ & $84.3 \pm 2.5$ \\
\hline & \multicolumn{4}{|c|}{$2 \%$ w/v Myrj 52 in $0.005 \mathrm{M}$ hydrochloric acid } \\
\hline & \multicolumn{4}{|c|}{$\%$ Artemether release (mean $\pm S D$ ) } \\
\hline 30 & $46.7 \pm 2.7$ & $55.8 \pm 2.7$ & $58.5 \pm 3.2$ & $69.4 \pm 1.9$ \\
\hline 60 & $65.2 \pm 2.4$ & $79.7 \pm 2.2$ & $84.9 \pm 2.6$ & $94.5 \pm 0.9$ \\
\hline 90 & $82.6 \pm 1.7$ & $92.7 \pm 1.8$ & $99.2 \pm 1.5$ & $100.1 \pm 0.9$ \\
\hline \multirow[t]{2}{*}{120} & $86.5 \pm 1.8$ & $98.9 \pm 1.3$ & $100.2 \pm 1.2$ & $100.8 \pm 0.7$ \\
\hline & \multicolumn{4}{|c|}{$\%$ Lumefantrine release (mean $\pm S D)$} \\
\hline 30 & $34.4 \pm 2.2$ & $36.4 \pm 1.5$ & $40.3 \pm 2.2$ & $47.8 \pm 2.2$ \\
\hline 60 & $53.4 \pm 2.7$ & $54.3 \pm 2.2$ & $59.8 \pm 2.6$ & $68.5 \pm 2.0$ \\
\hline 90 & $62.7 \pm 2.7$ & $64.4 \pm 2.6$ & $75.7 \pm 2.6$ & $93.4 \pm 1.2$ \\
\hline 120 & $67.6 \pm 2.5$ & $69.3 \pm 2.3$ & $83.4 \pm 1.9$ & $100.7 \pm 1.1$ \\
\hline
\end{tabular}

standard and sample solution, respectively. The purity angle value, being less than the purity threshold value, indicates that the peaks are spectrally pure in standard and sample solutions.

\section{Filter validation}

The filtration procedure for artemether and lumefantrine standard and sample solutions was evaluated using three different types of filters, namely, $0.45 \mu$ mdi nylon filter $(A)$, $0.45 \mu$ Whatman PTFE (B) filter and No. 42 Whatman filter paper $(C)$.
The centrifuged solutions of the standard and sample were compared with the filtered solutions in terms of \% recovery. The percentage peak area difference between the centrifuged solutions and solutions filtered through filters $A, B$ and $C$ was less than $1 \%$ indicating that loss during filtration is within the acceptable limits.

\section{Stability of solution}

The stability of standard and sample solutions was studied for $24 \mathrm{~h}$ at room temperature. The standard and sample solutions were stable in $2 \%$ w/v Myrj 52 in 
Table 4: Dissolution profile of reference products A, B, C and test product in 2\% w/v Myrj 52 in $0.005 \mathrm{M}$ hydrochloric acid using paddle at $100 \mathrm{rpm}(\mathrm{n}=24)$

\begin{tabular}{|c|c|c|c|c|c|c|c|}
\hline $\begin{array}{l}\text { Time } \\
\text { (min) }\end{array}$ & $\begin{array}{l}\text { Reference } \\
\text { Product A }\end{array}$ & $\begin{array}{l}\text { Reference } \\
\text { Product B }\end{array}$ & $\begin{array}{c}\text { Referen } \\
\text { ce } \\
\text { Product } \\
\text { C }\end{array}$ & $\begin{array}{c}\text { Test } \\
\text { Product T- } \\
1 \\
\text { (Hardness } \\
\text { : About } 80 \\
\mathrm{~N} \text { ) }\end{array}$ & $\begin{array}{c}\text { Test Product } \\
\text { T-2 } \\
\text { (Hardness: } \\
\text { About } 40 \text { N) }\end{array}$ & $\begin{array}{c}\text { Test } \\
\text { Product T-1 } \\
40^{\circ} \mathrm{C} / 75 \% \\
\mathrm{RH} \\
15 \text { days }\end{array}$ & $\begin{array}{c}\text { Test } \\
\text { Product T-2 } \\
40^{\circ} \mathrm{C} / 75 \% \\
\mathrm{RH} \\
15 \text { days }\end{array}$ \\
\hline & \multicolumn{7}{|c|}{$\%$ Artemether release (mean \pm SD) } \\
\hline 15 & $58.3 \pm 2.2$ & $66.2 \pm 2.3$ & $\begin{array}{l}72.3 \pm \\
3.6\end{array}$ & $46.2 \pm 2.4$ & $67.6 \pm 2.9$ & $33.4 \pm 3.1$ & $54.7 \pm 3.4$ \\
\hline 30 & $69.4 \pm 1.9$ & $76.4 \pm 2.1$ & $\begin{array}{c}85.4 \pm \\
2.9\end{array}$ & $58.9 \pm 2.8$ & $76.4 \pm 2.4$ & $49.5 \pm 3.4$ & $65.9 \pm 3.1$ \\
\hline 60 & $94.5 \pm 0.9$ & $95.1 \pm 1.9$ & $\begin{array}{c}98.4 \pm \\
1.4\end{array}$ & $71.4 \pm 1.9$ & $90.3 \pm 1.7$ & $59.6 \pm 2.7$ & $81.7 \pm 2.8$ \\
\hline 90 & $100.1 \pm 0.9$ & $99.8 \pm 1.1$ & $\begin{array}{c}100.1 \pm \\
1.1\end{array}$ & $79.5 \pm 1.5$ & $100.5 \pm 1.2$ & $64.8 \pm 2.9$ & $89.8 \pm 2.7$ \\
\hline 120 & $100.8 \pm 0.7$ & $100.5 \pm 0.9$ & $\begin{array}{c}101.3 \pm \\
0.8\end{array}$ & $88.3 \pm 1.7$ & $100.5 \pm 0.9$ & $74.7 \pm 2.4$ & $98.5 \pm 1.5$ \\
\hline f1 (Diff & nce factor) & 6.98 & 15.26 & 18.62 & 9.23 & 33.35 & 9.37 \\
\hline \multicolumn{2}{|c|}{ f2 (Similarity factor) } & 60.43 & 45.12 & 39.01 & 57.09 & 26.98 & 53.15 \\
\hline \multicolumn{8}{|c|}{$\%$ Lumefantrine release (mean $\pm S D$ ) } \\
\hline 15 & $38.7 \pm 1.8$ & $29.2 \pm 1.2$ & $\begin{array}{c}37.4 \pm \\
1.6\end{array}$ & $23.4 \pm 1.3$ & $30.1 \pm 3.1$ & $17.8 \pm 2.1$ & $26.3 \pm 2.9$ \\
\hline 30 & $47.8 \pm 2.2$ & $46.3 \pm 1.8$ & $\begin{array}{c}59.3 \pm \\
2.4\end{array}$ & $35.7 \pm 1.8$ & $44.9 \pm 2.8$ & $26.2 \pm 2.6$ & $39.4 \pm 3.1$ \\
\hline 60 & $68.5 \pm 2.0$ & $72.1 \pm 2.1$ & $\begin{array}{l}82.1 \pm \\
2.8\end{array}$ & $51.9 \pm 2.9$ & $74.3 \pm 2.4$ & $39.7 \pm 2.8$ & $67.6 \pm 2.9$ \\
\hline 90 & $93.4 \pm 1.2$ & $87.4 \pm 2.8$ & $\begin{array}{c}96.4 \pm \\
1.1\end{array}$ & $69.4 \pm 2.5$ & $92.7 \pm 2.0$ & $55.7 \pm 2.9$ & $83.7 \pm 2.5$ \\
\hline 120 & $100.7 \pm 1.1$ & $96.3 \pm 2.6$ & $\begin{array}{c}100.2 \pm \\
0.9\end{array}$ & $78.7 \pm 2.7$ & $99.8 \pm 1.2$ & $65.9 \pm 3.0$ & $92.4 \pm 1.9$ \\
\hline \multicolumn{2}{|c|}{$\begin{array}{l}\text { f1 (Difference factor) } \\
\text { f2 (Similarity factor) }\end{array}$} & $\begin{array}{c}8.29 \\
60.98 \\
\end{array}$ & $\begin{array}{l}11.84 \\
52.03 \\
\end{array}$ & $\begin{array}{l}25.78 \\
36.58 \\
\end{array}$ & $\begin{array}{c}7.25 \\
63.03 \\
\end{array}$ & $\begin{array}{l}41.19 \\
26.46 \\
\end{array}$ & $\begin{array}{l}11.37 \\
52.61 \\
\end{array}$ \\
\hline
\end{tabular}

$0.005 \mathrm{M}$ hydrochloric acid for a minimum period of $24 \mathrm{~h}$.

\section{Robustness}

The robustness of the method was evaluated by the varying chromatographic conditions of wavelength, flow rate, $\mathrm{pH}$ and composition of mobile phase of the analytical method. As per the standard test method, the wavelength was $216 \mathrm{~nm}$, flow rate $1.0 \mathrm{ml} / \mathrm{min}, \mathrm{pH}$ of mobile phase 3.0 and composition of mobile phase 20:80 buffer:acetonitrile. To evaluate the robustness of the method, the chromatograms were recorded with detection wavelengths of $213 \mathrm{~nm}$ and $219 \mathrm{~nm}$, flow rate of $0.8 \mathrm{ml} /$ minute and $1.2 \mathrm{ml} /$ minute, mobile phase $\mathrm{pH}$ of 2.8 and 3.2 , and mobile phase composition of $22: 78$ and $18: 82 \mathrm{v} / \mathrm{v}$ of buffer : acetonitrile. The results of the chromatographic test under varied conditions indicated that the accuracy and precision are within the specified limits of $98-102 \%$ for accuracy and \%RSD of $\leq 2.0$ for precision. No significant change was observed in system suitability parameters such as resolution, tailing factor, number of theoretical plates and \%RSD for replicate injections of the standard.

\section{DISCUSSION}

The sink condition for artemether (a minimum solubility of $60 \mu \mathrm{g} / \mathrm{ml}$ ) may be achieved in all the dissolution media listed in Table 1 where- 
Umapathi et al

Table 5: Linearity of response of artemether and lumefantrine

\begin{tabular}{|c|c|c|c|c|}
\hline \multirow[b]{2}{*}{ Concentration (\%) } & \multicolumn{2}{|c|}{ Artemether } & \multicolumn{2}{|c|}{ Lumefantrine } \\
\hline & $\begin{array}{c}\text { Concentration } \\
(\mu \mathrm{g} / \mathrm{ml})\end{array}$ & $\begin{array}{c}\text { Area } \\
\text { Response }\end{array}$ & $\begin{array}{c}\text { Concentration } \\
(\mu \mathrm{g} / \mathrm{ml})\end{array}$ & $\begin{array}{c}\text { Area } \\
\text { Response }\end{array}$ \\
\hline 5 & 1.02 & 3078 & 6.03 & 1691399 \\
\hline 10 & 2.05 & 6187 & 12.05 & 3349978 \\
\hline 25 & 5.03 & 15781 & 30.07 & 8464426 \\
\hline 50 & 10.07 & 30993 & 60.11 & 16760389 \\
\hline 75 & 15.06 & 45454 & 90.06 & 25010957 \\
\hline 100 & 20.11 & 60697 & 120.04 & 33369990 \\
\hline 125 & 25.08 & 75497 & 150.12 & 42557238 \\
\hline 150 & 30.12 & 90809 & 180.04 & 50499341 \\
\hline \multirow{4}{*}{$\begin{array}{l}\text { Slope } \\
\text { Intercept } \\
\text { Linear equation } \\
\text { Correlation } \\
\text { coefficient }\end{array}$} & \multicolumn{2}{|c|}{3004.7} & \multicolumn{2}{|c|}{281157} \\
\hline & \multicolumn{2}{|c|}{295.32} & \multicolumn{2}{|c|}{79052} \\
\hline & \multicolumn{2}{|c|}{$y=3004.7 x+295.32$} & \multicolumn{2}{|c|}{$y=281157 x-79052$} \\
\hline & \multicolumn{2}{|c|}{0.9999} & \multicolumn{2}{|c|}{0.9999} \\
\hline
\end{tabular}

as the sink condition for lumefantrine (a minimum solubility of $360 \mu \mathrm{g} / \mathrm{ml}$ ) may be achieved only in $\mathrm{HCl}$ containing more than 1 $\% w / v$ of Myrj 52 . Lumefantrine is practically insoluble in $0.1 \mathrm{M} \mathrm{HCl}, \mathrm{pH} 4.5$ acetate buffer, $\mathrm{pH} 6.8$ phosphate buffer and in water. Addition of a solubilising agent to these media resulted in various levels of solubility of lumefantrine in these media. Although the solubility of lumefantrine in $\mathrm{HCl}$ containing Myrj 52 was satisfactory, it was observed that the stability of lumefantrine in $\mathrm{HCl}$ in the presence of Myrj 52 increased as the molarity of $\mathrm{HCl}$ decreased. On this basis, the dissolution medium of $1 \% \mathrm{w} / \mathrm{v}$ of Myrj 52 in $0.005 \mathrm{M} \mathrm{HCl}$ was stable and provided sink conditions for artemether and lumefantrine.

To verify the suitability of $1 \% \mathrm{w} / \mathrm{v}$ of Myrj 52 in $0.005 \mathrm{M} \mathrm{HCl}$ as dissolution medium, dissolution release from reference product $A$ was checked in three different dissolution media of 1, 1.5 and $2 \% \mathrm{w} / \mathrm{v}$ Myrj 52 in $0.005 \mathrm{M} \mathrm{HCl}$. The test was performed with a volume of $1000 \mathrm{ml}$ of each dissolution medium using USP dissolution apparatus type 1 (basket) and type 2 (paddle) with different rates of stirring. At a stirring rate of $100 \mathrm{rpm}$ of paddle, the release of artemether was above $90 \%$ in all the three media but the release of lumefantrine was above $90 \%$ only in $2 \% w / v$ of Myrj 52 in $0.005 \mathrm{M} \mathrm{HCl}$. Lumefantrine release was about $73 \%$ in 1
$\% w / v$ of Myrj 52 in $0.005 \mathrm{M} \mathrm{HCl}$ and $84 \%$ in $1.5 \% \mathrm{w} / \mathrm{v}$ of Myrj 52 in $0.005 \mathrm{~N} \mathrm{HCl}$.

The results obtained show that the medium of $2 \% \mathrm{w} / \mathrm{v}$ Myrj 52 in $0.005 \mathrm{M} \mathrm{HCl}$ with a stirring rate of $100 \mathrm{rpm}$ for paddle was able to release 100.8 and $100.7 \%$ of artemether and lumefantrine, respectively, from reference product $A$ in $120 \mathrm{~min}$.

Therefore, this dissolution medium using paddle at $100 \mathrm{rpm}$ for 120 minutes was selected for the dissolution test. The discriminating power of the selected method was verified by analyzing the three reference products ( $A, B$ and $C$ ), two in-house prepared test products with different hardness and inhouse test products exposed to $40{ }^{\circ} \mathrm{C} / 75 \%$ $\mathrm{RH}$ conditions for 15 days in an open dish. The dissolution results presented show that the proposed dissolution test has satisfactory discriminating power to distinguish the release profiles of the different reference products, the in-house products of different hardness and the in-house products which were exposed to heat and humidity. MannWhitney $U$ test was applied to the data to find out whether each group of dissolution release values at a particular time point is different for different formulations. For example, the dissolution release values at $15 \mathrm{~min}$ of reference product $A$ were compared with the dissolution release values of test product 1 
(T1) using Mann-Whitney $U$ test. Each of the $z$ values obtained was $>1.96$. The $z$ value of 1.96 is the critical value for a two-tailed test at the level of significance of $5 \%(p=0.05)$. Since the $z$ values were $>1.96$, it was inferred that the groups of values being compared are different from each other at $p=$ 0.05 . This showed that the dissolution method is able to produce results which are different for different formulations at the various time points.

Typical acceptance criteria for dissolution release of drugs from immediate release tablets is about $80 \%$ of labeled amount in 45 minutes [15]. Using $2 \% \mathrm{w} / \mathrm{v}$ Myrj 52 in $0.005 \mathrm{M} \mathrm{HCl}$ with paddle at $100 \mathrm{rpm}, 95 \%$ of artemether was released in 60 min from each of the reference products ( $A, B$ and $C$ ) whereas above $95 \%$ of lumefantrine was released only around $120 \mathrm{~min}$. Hence, with 2 $\% w / v$ Myrj 52 in $0.005 \mathrm{M} \mathrm{HCl}$ as dissolution medium and with a stirring rate of $100 \mathrm{rpm}$ with paddle, the suggested dissolution release acceptance limit would not be less than $85 \%$ of artemether in $60 \mathrm{~min}$ and not less than $85 \%$ of lumefantrine in $120 \mathrm{~min}$. A single time point of not less than $85 \%$ release of each drug in 120 min may be considered for quality control test. However, the in-house limit for a particular tablet formulation of artemether and lumefantrine ought to be fixed on the basis of its dissolution performance using the developed method.

The HPLC method used for the determination of dissolution release of artemether and lumefantrine from tablets were validated in terms of accuracy, precision, linearity, specificity, filter validation, solution stability and robustness. The results of validation showed that all the validation parameters are satisfactory. The peak areas of artemether and lumifantrine peaks were linear with respect to concentration. The correlation coefficient values of 0.9999 indicate excellent correlation between response (peak area) and concentration.

\section{CONCLUSION}

The proposed dissolution test method for artemether and lumefantrine in tablets provides sink condition and is able to satisfactorily discriminate drug release between formulations differing in terms of hardness, exposure to heat and moisture and composition of excipients. The analysis was carried out by a HPLC method which was validated. Hence the proposed dissolution method may be used as a single test method for the routine dissolution testing of tablets containing artemether and lumefantrine.

\section{ACKNOWLEDGEMENT}

This work was supported by Micro Labs Limited, India and Shanmuga Arts, Science, Technology \& Research Academy, India.

\section{REFERENCES}

1. Sagar $D M$, Shobana $S$, Sulabha $P$, Vandana $B P$. Development of SMEDDS using natural lipophile: Application to B - Artemether delivery. Int J Pharm 2008; 362: 179-183.

2. Punit PS, Rajashree CM. Development and Evaluation of Artemether Taste Masked Rapid Disintegrating Tablets with Improved Dissolution Using Solid Dispersion Technique. AAPS PharmSciTech. 2008; 9: 494-500.

3. WHO : Model List of Essential Medicines for Children. $2^{\text {nd }}$ List; 2010 [http://www.who.int/ medicines/publications/essentialmedicines/en/i ndex.html] [cited 2010, October 6]

4. Roger B, Richard T,Kimberly H, Amir A. Physical and Chemical Stability of expired fixed dose combination artemether-lumefantrine in uncontrolled tropical conditions. Malarial J. 2009; 1 -7

5. The Electronic Medicines Compendium; Riamet; Summary of Product Characteristics; 2010 [http://www.medicines.org.uk/emc/medicine/91 96] [cited 2010, October 6]

6. WHO: Artemether and Lumefantrine Tablets; Final Text for addition to The International Pharmacopoeia; QAS/07.192/Final. Available: http://www.who.int/medicines/publications/phar macopoeia/mon_mal/en/index.html] [cited 2010, October 6]

7. USP SALMOUS Standards Guideline, 2009. Lumefantrine and Artemether Tablets. (http://apps.who.int/phint/en/p/docf/anchor, rea ding-docs.html) [cited 2010, October 6] 
8. Rahman SMH, Telny TC, Ravi TK, Kuppusamy S. Role of surfactant and $\mathrm{pH}$ in dissolution of curcumin. Ind. J. Pharm.Sci. 2009; 71: 139142.

9. Ana RB, ClesioSP, Martin S, Effrides ESS. development and validation of dissolution tests for fexofenadine hydrochloride capsules and coated tablets. J.Pharm. Pharmceut Sci. 2005; 8: 289-298.

10. Madura VD, Vandana TG, Pranav PJ. Dissolution method development and validation for combination of cefixime trihydrate and erdosteine capsules. J.Pharmacy Research. 2009; 2: 1700-1704.

11. Silvia HMG, Lutiane $P$, Marcela ZA, Ozoame $B$, Simone GC. Development and validation of a dissolution method with spectrophotometric analysis for diacerhein capsules. Sci. Pharm. 2008; 76: 541-554

12. United States Pharmacopoeia and National Formulary (USP 31-NF26). Rockville, MD: US Pharmacopoeia 2008; pp 683-687

13. ICH Guideline 1996. Validation of Analytical Procedures. Available from http://private.ich .org/LOB/media/MEDIA417.pdf [cited 2011, May 24]

14. Mann-Whitney Test VassarStats: Statistical Computation Web Site: Available from : faculty.vassar.edu/lowry/VassarStats. html [cited 2011, March 3]

15. Expression of Dissolution Specifications for Oral Dosage Forms, British Pharmacopoeia, 2011; Appendix XIIB: A318 